\title{
Cinsel İstismar Olgularında Adli Görüişme Odalarının Kullanımı: Hâkim, Avukat, Uzman ve Mağdur Görüșleri
}

\author{
Use of Forensic Interview Rooms in Sexual Abuse Lawsuits: The Views \\ of Judges, Lawyers, Specialists and Victims
}

\section{Ayşe Dolunay SARICA ${ }^{1}$ @), Umut Haydar COŞKUN² ${ }^{\circledR}$}

${ }^{1}$ Doç. Dr., Dokuz Eylül Üniversitesi, Eğitim Fakültesi, İzmir, Türkiye

${ }^{2}$ Doktora Öğrencisi, Dokuz Eylül Üniversitesi, Eğitim Fakültesi, İzmir, Türkiye

ORCID: A.D.S. 0000-0003-3626-9469; U.H.C. 0000-0002-0892-8175

*Teşekkür: Adalet Bakanlığı́nın ses ve görüntü kaydına izin vermemesi sebebiyle görüşmelere yardımcı olarak katılım sağlayan Yeliz Coşkun.

Öz

Günümüzde cinsel istismar mağdurlarıla ilgili koruyucu ve destekleyici önlemler almak önemli bir kamu görevi olarak değerlendirilmeye başlanmış, bu doğrultuda dünya genelinde gündeme gelen Adli Görüşme Odası (AGO) uygulamaları, son dönemlerde Türk Adli Sistemi içerisinde de yerini almıştır. AGO'nun, dava süreçlerini ve başta mağdurlar olmak üzere, süreci deneyimleyen hâkimleri, avukatları ve aile mahkemesi uzmanlarını ne şekilde etkilediğine ilişkin yerli alanyazına gereksinim vardır. Dolayısıyla bu araştırmada, çocuğa yönelik cinsel istismar davalarında AGO uygulamalarının hâkim, avukat, aile mahkemesi uzmanı ve mağdur görüşleri çerçevesinde değerlendirilmesi amaçlanmıștır. Nitel olarak desenlenen araştırma, İzmir Adliyesi'ne yansımış çocuğa yönelik cinsel istismar davalarında görev alan 10 hâkim, 10 avukat ve 10 aile mahkemesi uzmanı ile 10 mağdur çocuk/ergenle gerçekleştirilmiştir. Dört katılımcı grup için araştırmacılar tarafından geliștirilen yarı-yapılandırılmıs görüșme formları kullanılarak yürütülen niteliksel çalışmada toplanan veriler, araştırmacılar tarafından içerik analiziyle analiz edilmiștir. Bulgular, dört katılımcı grubun AGO uygulamasını gerekli ve yararlı bulduğunu göstermiştir. Bunun yanında bazı hâkim, avukat ve aile mahkemesi uzmanları doğrudanlık ilkesini öne sürmüş ve belirli koşulların sağlandığı takdirde mağdur çocukların mahkemede dinlenmesinin de gerekli olduğunu ifade etmişlerdir. Hâkimler, avukatlar ve uzmanlar ayrıca teknik sorunların süreci olumsuz etkilediğini de belirtmişlerdir. Anahtar Kelimeler: Cinsel istismar, çocuk, adli görüşme odası

\section{ABSTRACT}

Recent trends show that establishing protective and supportive policies for victims of sexual abuse became an important public issue, leading to a worldwide use of Forensic Interview Rooms (FIR), which has recently come up within the Turkish Judicial System. There seems to be a lack of evidence regarding the impact of FIR on sexual abuse cases as well as the victims, the judges, the lawyers and the family court specialists. Therefore, this study aimed at investigating the impact of FIR in child sexual abuse cases from the eyes of judges, lawyers, family court specialists and child victims. This qualitative study was conducted with 10 judges, 10 lawyers and 10 family court specialists serving in child sexual abuse cases in the Izmir Judicial Court, and 10 child victims. Data were gathered via semi-structured interviews developed by the authors and analyzed using content analysis. According to the results, the four groups of participants found FIR necessary and beneficial. However some of the judges, lawyers and specialists, on the basis of the principle of directness, claimed children should be heard in court as long as the necessary conditions are met. Judges, lawyers and specialists also brought up the negative impact of technical problems on the lawsuits.

Keywords: Sexual abuse, child, forensic interview room

Submitted: 19.09.2019 • Revision Requested: 13.01.2020 • Last Revision Received: 02.04.2020 • Accepted: 17.04.2020 • Published Online: 04.05.2020

Corresponding author: Umut Haydar Coşkun, E-mail: uhcoskun@hotmail.com

Citation: Sarica AD, Coskun UH, 'Cinsel İstismar Olgularında Adli Görüşme Odalarının Kullanımı: Hâkim, Avukat, Uzman ve Mağdur Görüssleri' (2020) 8(1) Ceza Hukuku ve Kriminoloji Dergisi-Journal of Penal Law and Criminology, 117. https://doi.org/10.26650/JPLC2019-0020 


\section{EXTENDED ABSTRACT}

Beginning in the 1990s, sexual abuse has begun to be a critical issue around the World due to its negative physical and emotional impact on the victims and related others. Since then, establishing protective and supportive policies for (especially child) victims of sexual abuse became a major public issue, leading to a worldwide use of Forensic Interview Rooms (FIR) in taking a child's statement in child sexual abuse cases. The Turkish Judicial System has also recently taken an important step in using FIR in such cases.

FIR was developed as an alternative and secure setting to take children's statements in cases where it might be threatening for the child to be in the court room. FIR is a unit in the court house including a waiting room, an interview room with a closed circuit TV system and play and related materials, and an observation room where the recording takes place and related personnel can observe the child interview. The family court specialist conducts the interviews with the child victim individually in the interview room while the judge can make direct contact with the specialist through an earphone in order to ask case related questions to the victim. The pedagological background of the specialist assists him/her in rewording the questions to the child so as to avoid additional emotional damage.

As outlined above, FIR creates a child friendly environment where the child will not have to go through any pressure, and probably give his/her statement more reliably compared to the court room. Despite its positive effects on the child and the case, we do not have enough evidence to justify this new procedure, and there seems to be a need to understand what FIR has brought for related parties, including judges, lawyers, family court specialists and child victims of sexual abuse. Therefore, this study aimed at investigating the impact of FIR in child sexual abuse cases through the eyes of judges, lawyers, family court specialists and child victims.

The participants of this qualitative study included 10 judges, 10 lawyers and 10 family court specialists serving in child sexual abuse cases seen in the Izmir Judicial Court, and 10 child victims. Four semi-structured interview forms were developed by the authors for each group of participants. The face and content validity of the forms were tested by two experts in the field (two experts for each form, making up a total of five experts). Individual interviews were conducted by the second author in the court house. All data were analyzed independently by the two authors via content analysis. Any discrepancies were resolved through a 2-hour discussion. 
Results from the four groups generally showed that FIR was a necessary and beneficial procedure for child victims of sexual abuse. Despite these positive attitudes, some of the judges and lawyers stressed the importance of the principle of directness, and believed that, under optimal circumstances, children should be heard directly by the judge in the court room. It should be noted however that, FIR with its camera and earphone system, can be said to hinder the principle of directness in minimal terms, since the judge can follow the child's mimics and gestures while asking all his/her questions to the specialist. This stick to old habits exhibited by the judges was believed to eventually change with the spread of FIR practices across the nation.

According to the lawyers, the tendency of the judges to stick with the principle of directness resulted in declining lawyer requests for FIR. However, FIR procedures should be a legal requirement independent of judge preference in order for all victims to be treated equally in lawsuits. This may be achieved through legal sanctions and developing inservice training programs for judges. It may also be noted that, lawyers as well as judges should be provided with inservice training regarding FIR procedures in order to increase their FIR requests in child sexual abuse cases. Family court specialists on the other hand, had positive attitudes towards FIR compared to judges and lawyers, believing that they were more able to practice their profession within a better planned schedule.

Another important finding from the study was the technical problems and lack of materials put forward by the court personnel. Most of the participants complained about the communication breakdowns between the judge and the specialist due to frequent line cut-offs during the interviews. The participants also brought up the lack of toys and materials in FIR. They claimed that children should be kept busy with developmentally appropriate toys and materials while waiting for the interview or that a specialist needs to make the child feel comfortable and safe during the interview. These issues were thought to be hindering factors for some of the participants' resistance to FIR. Last but not least, the child participants all reported that FIR was very beneficial for them during the trials.

Taken together, the child's best interest was concidered important by the court personnel while some change in attitudes, tendencies and technical issues is urgently needed to make FIR a common practice in Turkish courts. 


\section{Giriș}

Çocukların güvenli bir ortamda yetişme ve gelişme hakları, toplumsal kurallar ve anayasal boyutta bir temel hak olarak tanımlanmasına karşın, bu hak zaman zaman çocukların etkileşim içerisinde oldukları bireyler tarafından ihlal edilebilmekte ve cinsel istismar eylemi gerçekleşebilmektedir (Masilo, 2018). Gerçekleşen cinsel istismar öyküsü ise, genellikle anneler olmak üzere bazı aile üyelerinde çocuğu koruyamadıklarına yönelik bir suçluluk duygusunu ortaya çıkarabilmekte, çocuğun çevresinde olumsuz bir ortamın oluşmasına neden olabilmektedir (Azzopardi, Alaggia ve Fallon, 2018).

Cinsel istismar, kısa ve uzun vadede mağduru fiziksel ve psikolojik olarak etkileyen bir sorun olmasına, mağdurun çevresindeki pek çok kişiyi de etkilemesine karşın (Azzopardi ve diğerleri, 2018; Pilgrim, 2017; Scoglio, Kraus, Saczynski, Jooma ve Molnar, 2019), 1990'lı yıllara kadar Amerika Birleşik Devletleri ve Batı Avrupa ülkelerinde akademik ya da toplumsal açıdan gereken önemin verilmediği bir alan olarak karşımıza çıkmaktadır (Blakemore, Herbert, Arney ve Parkinson, 2017; Rellini, 2014; Renzoive, 2018). Nitekim pek çok araştırma, cinsel istismarın mağdur üzerinde yarattığı psikiyatrik durumlara işaret etmekte ve söz konusu ağır durumlar arasında travma sonrası stres bozukluğu, davranış bozuklukları, depresyon, madde kullanım bozukluğu ve kişilik bozuklukları gelmektedir (Pérez-Fuentes, Olfson ve diğerleri, 2013; Renzoive, 2017; Taner, Çetin, Işsk ve İşeri, 2015).

Günümüzde cinsel istismara yönelik bakış açısı değişmiş, cinsel istismar mağdurları ile ilgili koruyucu ve destekleyici önlemler almak ve mağdura süreç boyunca güvende olduğunu hissettirmek bir kamu görevi olarak değerlendirilmeye başlanmıştır (Tetteh ve Markwei, 2018; Tweedlie ve Vincent, 2019). Bu değişimde, cinsel istismar öykülerinin medyada sıkça yer almasıyla oluşan kamuoyu talepleri de önemli rol oynamıştır. Ne var ki mağdurlara ait fotoğraf, video gibi özel yaşama ait içeriklerin medyada uygun olmayan şekillerde sergilenmesi, mağdurların örselenmesine yol açmış ve bu olumsuz tablo cinsel istismar mağduru pek çok bireyin yardım talebinden kaçınmasına neden olmuştur (Hornor ve Zero, 2018; Popović, 2018). Cinsel istismar davalarında ayrıca, uzun yargılama süreci ve tıbbi muayenenin herhangi bir bulgu vermemesi gibi faktörler mağdurların suçluluk duymalarına neden olmakta, bu gibi durumlar kendini savunmasız hisseden diğer cinsel istismar mağdurlarının yardım talebinde bulunmamalarının diğer nedenleri arasında sayılmaktadır (Joki-Erkkilä, Niemi ve Ellonen, 2018; Tetteh ve Markwei, 2018). 
Toplumsal değişimler ve talepler nedeniyle pek çok disiplin cinsel istismarı ve cinsel istismar mağdurlarını biyolojik, psikolojik, nörolojik, davranışsal ve sosyolojik açıdan ele almaya çalışmış, bu çabayla birlikte yeni paradigmalar ortaya çıkmıştır (Azzopardi ve diğerleri, 2018). Özellikle hukuk alanında yeni bir bakış açısı gelişerek çocuğun üstün yararı ilkesi gündeme gelmiş ve her koşulda uygulanması öngörülmüştür. Çocuğun üstün yararı, çocukların etkilenebileceği tüm karar ve işlemlerde çocuğun maddi manevi yararının öncelikle gözetilmesi olarak tanımlanabilir. Türkiye'nin de taraf olduğu Lanzarote Sözleşmesi’nde, çocukların üstün yararı ilkesi temel alınmış, önleyici ve koruyucu düzenlemelerin önemi, mağdur çocuk ve ailesine yardım edilmesi, çocuklara koruyucu cinsel eğitim verilmesi, adli süreçlerin çocuk dostu yöntemlerle düzenlenmesinin önemi vurgulanmıştır. Bu doğrultuda düzenlenen uygulamalar arasında adli görüşme uygulaması yer almaktadır. Adli görüşme, mağdurun korunması ve örselenmemesi yaklaşımına dayanarak adli yargılamada mağdurun stres yaşamadan beyanını sağlıklı bir şekilde verebilmesi ihtiyacından doğmuştur (Bracewell, 2018; Krause-Parello, Thames, Ray ve Kolassa, 2018). Başta okul öncesi çocuklar olmak üzere tüm yaş gruplarındaki cinsel istismar mağdurlarının ifadesini almakta zorlandığını ifade eden hâkimler ve savcılar bu uygulamanın yaygınlaşmasında büyük rol oynamıştır (Ernberg, Magnusson ve Landström, 2018).

Dünya genelinde uzmanların adli görüşme odalarında (AGO) cinsel istismar mağdurlarıyla görüşme gerçekleştirmeleri yaygın bir uygulamadır. Bu uzmanlar, mağdurla bir ön görüşme yaparak öncelikle onunla güvene dayalı bir etkileşim geliştirmekle, ona kendini güvende olduğunu hissettirmekle, bunun sonrasında mağdurun ihtiyaçlarını belirleyip gerekli yönlendirmeleri yapmakla ve son aşamada cinsel istismar öyküsü ile ilgili bilgi toplamakla yükümlüdür (Krause-Parello ve diğerleri, 2018). Uzmanların ayrıca bu görüşmeler esnasında, mağdurun psiko-sosyal gelişimine olabildiğince zarar vermeme gayretinde olmaları esastır (Demirel ve Atalar, 2017). Söz konusu girişimi sistematik bir düzeye taşımak amacıyla yurt dışında birtakım görüşme protokolleri gündeme getirilmiştir. Bunlar arasında NICHD (National Institute of Child Health and Human Development Protocol - Ulusal Çocuk Sağlığı ve İnsan Gelişimi Enstitüsü Protokolü) (Lamb, Orbach, Hershkowitz, Esplin ve Horowitz, 2007) ve RATAC (Rapport, Anatomy, Identification, Touch Inquiry, Abuse Scenario, Closure - Güven, Anatomi, İsimlendirme, Dokunmayı Sorgulama, İstismar Senaryosu, İfşa Etme) (Anderson, Ellefson, Lashley ve Miller, 2009) gelmektedir. Her iki protokolde, çocukla gerçekleştirilecek olan görüşmede güven oluşturmadan olayın çocuk tarafindan açıklanmasına kadar olan adımlar tanımlanmakta ve görüşmecilerin bu adımları harfiyen 
takip etmeleri beklenmektedir. Toth (2011), mağdur çocuklara istismarla ilgili soruların doğrudan sorulmasından ziyade, NICHD ve RATAC gibi protokollerin kullanımının daha etkili olduğunu ve benzer sistematik bilgi toplama süreçlerinin geliştirilmesi gerektiğini savunan yazarlar arasındadır. Amerika Birleşik Devletleri'nde Çocuk Savunma Merkezleri’nde (Child Advocacy Center) yürütülen sistematik adli görüşmeler sonrasında çocuğa tıbbi ve diğer koruyucu hizmetlerin de sunulması girişimleri mevcuttur (Cross, Jones, Walsh, Simone ve Kolko, 2007). Bu tür hizmet modelinin çocuklar ve dava üzerinde olumlu etkiler yarattığına dair çalışmalara rastlamak mümkündür (örneğin, Cronch, Viljoen ve Hansen, 2006).

Türkiye'de adli görüşmelerin yasal çerçevede belirli bir standarda oturtulma çabası, Adalet Bakanlığı, İçişleri Bakanlığı, Millî Eğitim Bakanlığı, Aile ve Sosyal Politikalar Bakanlığg ve üniversitelerin çocuk birimlerinin bir yıl süren koordineli çalışmalarının sonucunda 2010 yılından itibaren adliye saraylarından bağımsız yapılar olmak koşuluyla Çocuk İzlem Merkezleri (ÇİM) kurulması ile gündeme gelmiştir. ÇİMler cinsel istismar mağduru çocukların ikincil örselenmelerinin önüne geçmek ve istismar olgusuyla ilgili hızlı ve kapsamlı bilgi edinmek amacıyla, ABD'de olduğu gibi (Cronch ve diğerleri, 2006, Cross ve diğerleri, 2007), adli, tıbbi ve sosyal bilimler alanlarında yetişmiş uzmanların multidisipliner çalışmalarıyla süreci yürüten merkezlerdir (Acehan, Bilen ve diğerleri, 2013; Aydemir ve Yurtkulu, 2012; Bağ ve Alşen, 2016; Bilginer ve Çalışkan, 2018). Nisan 2019 itibariyle Türkiye'de 35 ilde toplam 38 Çocuk İzlem Merkezi bulunmaktadır (Sağlık Bakanlığı, 2019). Çı̇M alanyazını, genel olarak bu merkezlerin multidisipliner yapılarının ve 7/24 hizmet vermelerinin, olgularla ilgili hızlı ve güvenilir bilgilere ulaşılmasında etkili olduğunu ileri sürmekte, ancak söz konusu görüşlerin bilimsel bulgulardan ziyade araştırmacıların kişisel deneyimlerine dayandığı görülmektedir (Acehan, Bilen ve diğerleri, 2013; Aydemir ve Yurtkulu, 2012; Bağ ve Alşen, 2016; Bilginer ve Çalışkan, 2018). Bununla birlikte aynı çalışmalar, ÇİM'in bulunmadığı illerde, cinsel istismar mağduru çocukların mahkeme salonlarında dinlenmesi uygulamasının süregittiğini, hatta ÇİM'in olduğu bazı illerde bazı hâkimlerin çocukları mahkeme salonunda ikinci kez dinlemeyi talep ettiklerini vurgulamaktadırlar (Acehan, Bilen ve diğerleri, 2013; Aydemir ve Yurtkulu, 2012; Bağ ve Alşen, 2016; Bilginer ve Çalışkan, 2018).

ÇİMlerin çeşitli illerde kurulması ve işletilmesinin yanı sıra, Adalet Bakanlı̆̆ı Nisan 2017'den başlatılmak üzere, adliye saraylarındaki duruşma salonlarında dinlenen çocuklar ile ilgili yeni bir adım atmıştır. Bu yeni adımla, Adalet Bakanlığı'nın 2015- 
2019 Stratejik Planı'nda yer alan "Çocuk adalet sisteminde çocuğun etkin korunması için gerekli önlemlerin alınması ve kurumlar arası işbirliğinin güçlendirilmesi”, "Çocuklara yönelik adli süreçlerde özel önlemlerin etkin hâle getirilmesi", "Aile içi şiddetle mücadelede koruma ve soruşturmanın etkinliğinin artırllması" amacına uygun olarak, adliye saraylarının içinde Mağdur Hakları Daire Başkanlığı'na bağlı Adli Görüşme Odaları kurulmaya başlanmıştır. Bu kararlarla eş zamanlı olarak 23 ilde ve 26 adliyede faaliyete geçen AGOlarda, hâlihazırda Aile ve Çocuk Mahkemesi'nde görev yapmakta olan pedagoglar, psikologlar ve sosyal hizmet uzmanları görevlendirilmişlerdir. Mart 2019 itibariyle 49 ilde 59 AGO'nun kurulduğu bildirilmektedir (Ermağan-Çağlar ve Türk, 2019; Mağdur Hakları Daire Başkanlığı, 2019). Şunu belirtmek gerekir ki, AGOların kurulmasındaki amaç ÇiMlere alternatif oluşturmaktan ziyade, birlikte çalışarak çocuklara ve ailelerine uygun bir hizmet modeli sunmaktır. ÇìM Sağlık Bakanlığı koordinasyonuyla hastanelerin içinde yalnızca çocuk cinsel istismar mağdurlarına yönelik ve yalnızca kovuşturma aşamasında hizmet sunmaktayken, AGO Adalet Bakanlığı koordinasyonunda adliyeler içerisinde tüm kırılgan gruplara yönelik soruşturma ve kovuşturmalar ile aile mahkemeleri tarafindan kullanılabilmektedir (Adalet Bakanlığı Ceza İşleri Müdürlüğü Mağdur Hakları Daire Başkanlığı, 2017).

AGO, görüşme yapılacak kişinin bekleyebileceği ve gerektiğinde avukatıyla görüşebileceği bir bekleme odası, ses ve/veya görüntü kaydının alınabileceği görüşme odas1 ve adli görüşmeyi takip edecek hâkim, savc1, avukat, adli görüşme odası koordinatörü ve ilgili diğerlerinin bulunacağı gözlem odasından oluşmaktadır. Öncelikli olarak cinsel suç ve aile içi şiddet mağduru çocuklar için kurulmuş bu odalarda, çocukların beyanlarını duruşma salonunda karşılaşabilecekleri olumsuz koşullardan kaynaklanabilecek ikincil bir örselenme yaşamadan vermeleri hedeflenmektedir. İfade alımı sırasında görüşme odasında yalnızca uzman ve çocuk bulunmakta, hâkimler ve savcılar gözlem odasından ya da duruşma salonundan bu odaları izleyebilmekte, gerektiğinde mikrofon ve kulaklık aracılığıyla uzman ile iletişim kurarak mağdura sorular yöneltebilmektedirler. AGOlar'ın ayrıca her yaş grubundaki çocuklar ve ergenlere uygun fiziksel düzenlemeleri de içermesi gerekmektedir (Ermağan-Çağlar ve Türk, 2019; Mağdur Hakları Daire Başkanlığı, 2017).

Büyük olasılıkla yeni bir uygulama olmasından dolayı, AGO'ların cinsel istismar mağdurları ve davaların gidişatı üzerindeki sonuçlarına ilişkin yurtiçi alanyazına rastlamak güçtür. Ermağan-Çağlar ve Türk'ün (2019) güncel bir çalışmaları ise, 
Türkiye genelinde AGO görüşmelerinin standardize edilmesi yönünde NICHD Protololü'nü önermeleri bakımından önemli bir çalışma olarak kabul edilebilir. Nitekim yazarlar bu çalışmalarında, AGO görüşmelerinin standart bir protokol çerçevesinde geçerliğinin sağlanması, bir diğer deyişle çocuklardan doğru bilgilerin alınarak gereksiz hükümlerin ya da salıverilmelerin engellenmesi yönünde etkili bir çabayı gündeme getirmişlerdir.

AGO uygulamaları yoluyla geçerli ve güvenilir bilgi elde etmek için süreci birebir ve yoğun olarak deneyimleyen tüm tarafların (mağdurlar, uzmanlar, hâkimler, avukatlar) boylamsal olarak izlenmesi kuşkusuz ki çok değerli bir çaba olacaktır. Ne var ki, cinsel istismar gibi hassas bir konuda atılan AGO adımının etkilerine dair bilgilere daha kısa sürede ulaşmanın, bir diğer deyişle kesitsel bir araştırma gerçekleştirmenin kritik olduğu düşünülmektedir. Bu aşamada, AGO uygulamasını deneyimlemiş ilgili tüm tarafların görüşlerini almak uygun gibi görünmektedir. Dolayısıyla bu araştırmanın amacını, AGO sürecini deneyimlemiş cinsel istismar mağdurlarının, hâkimlerin, avukatların ve uzmanların, AGO uygulamasına ilişkin görüşlerinin belirlenmesi oluşturmuştur.

\section{Yöntem}

$\mathrm{Bu}$ araştırmada, bir konuda yoğun deneyimleri olan bireylerin o konuya ilişkin görüşlerini derinlemesine inceleme olanağı sağlayan ve nitel araştırma modellerinden biri olan temel nitel araştırma deseni tercih edilmiş̧ir (Glesne ve Peshkin, 1992; Huberman ve Miles, 1998; Yıldırım ve Şimşek, 2013). Temel nitel araştırmalarda araştırmacı, katılımcıların bir konuya ilişkin kişisel deneyimlerini nasıl değerlendirdiklerine ve anlam yüklediklerine odaklanır (Glesne ve Peshkin, 1992; Merriam, 2013). Veriler gözlem, görüşme ya da belgelere ulaşma yoluyla toplanmakta ve verinin uygunluğuna göre tekrar eden örüntülerin kategorize edilmesi ve temalar altında adlandırılması söz konusudur (Glesne ve Peshkin, 1992; Merriam, 2013; Somekh, 2006).

\section{1. Çalışma Grupları}

Araştırmanın çalışma grubu, İzmir Adliyesi Ağır Ceza Mahkemeleri’nde görev yapan 10 hâkim, İzmir Barosu'na kayıtlı olan 10 avukat, adli görüşmeci olarak görev yapan 10 uzman ve 10 cinsel istismar mağduru çocuk olmak üzere toplam 40 kişiden oluşmaktadır. Hâkim, avukat ve uzmanların demografik özellikleri Tablo 1'de özetlenmiştir. 
Tablo 1. Hâkimler, avukatlar ve aile mahkemesi uzmanlarının demografik özellikleri

\begin{tabular}{|l|c|c|c|c|}
\hline & & Hâkim* & Avukat* & Aile mahkemesi uzmanı* \\
\hline \multirow{3}{*}{ Yaş } & $26-35$ & 1 & 3 & 5 \\
& $36-45$ & 4 & 6 & 4 \\
& $46-\ldots$ & 5 & 1 & 1 \\
\hline \multirow{2}{*}{ Cinsiyet } & Erkek & 6 & 3 & 5 \\
\cline { 3 - 5 } & Kadın & 4 & 7 & 5 \\
\hline \multirow{3}{*}{ Görev Süresi (y1l) } & $0-5$ & - & 2 & 2 \\
\cline { 3 - 5 } & $6-10$ & 3 & 6 & 3 \\
\hline \multirow{2}{*}{ AGO eğitimi } & $11-20$ & 7 & 2 & 10 \\
\cline { 3 - 5 } & Alındı & - & 3 & - \\
\cline { 3 - 5 } & Alınmadı & 10 & 7 & 3 \\
\hline
\end{tabular}

$* \mathrm{n}=10$

Tablo 1 genel olarak incelendiğinde, hâkimlerin yaş ve görev süresi olarak avukat ve uzmanlardan üstün oldukları ve üç grupta da cinsiyet dağılımlarının eşit ya da eşite yakın olduğunu söylemek mümkündür. Tablo 2'de, katılımcı cinsel istismar mağdurlarına ilişkin bilgiler yer almaktadır.

Tablo 2. Cinsel istismar mağdurlarına ilișkin bilgiler

\begin{tabular}{|c|c|c|l|}
\hline Katılımc1 & Yaş & Cinsiyet & Dosya kapsamı \\
\hline 1 & 12 & $\mathrm{E}$ & $\begin{array}{l}\text { Çocuğun nitelikli cinsel istismarı, } \\
\text { Kişiyi hürriyetinden yoksun kı1ma }\end{array}$ \\
\hline 2 & 11 & $\mathrm{~K}$ & $\begin{array}{l}\text { Çocuğun nitelikli cinsel istismarı, } \\
\text { Tehdit }\end{array}$ \\
\hline 3 & 13 & $\mathrm{~K}$ & Çocuğun nitelikli cinsel istismarı \\
\hline 4 & 14 & $\mathrm{~K}$ & Çocuğun nitelikli cinsel istismarı \\
\hline 5 & 9 & $\mathrm{E}$ & $\begin{array}{l}\text { Çocuğun nitelikli cinsel istismarı, } \\
\text { Kişiyi hürriyetinden yoksun kılma }\end{array}$ \\
\hline 6 & 14 & $\mathrm{E}$ & Çocuğun nitelikli cinsel istismarı \\
\hline 7 & 8 & $\mathrm{~K}$ & Çocuğun nitelikli cinsel istismarı \\
\hline 8 & 11 & $\mathrm{~K}$ & Çocuğun nitelikli cinsel istismarı \\
\hline 9 & 10 & $\mathrm{~K}$ & Çocuğun nitelikli cinsel istismarı \\
\hline 10 & 12 & $\mathrm{~K}$ & Çocuğun nitelikli cinsel istismarı \\
\hline
\end{tabular}

Tablo 2'de yer alan bilgiler özetlenecek olursa, mağdurların 8-14 yaşlar arasında oldukları ve cinsiyet dağılımının kız lehine olduğu (\%70) görülmektedir.

\subsection{Veri Toplama Araçları}

Araştırmadan elde edilen veriler, araştırmacılar tarafından geliştirilen Hâkim, Avukat, Uzman ve Mağdur Görüşme Formları ile toplanmıştır. Katılımcıların yaş, cinsiyet ve görevdeki süre gibi demografik bilgileri, görüşmelerin başında katılımcılara sorularak her görüşme formunun üst bölümüne eklenen ilgili kutucuklara yazılarak elde edilmiştir. 
Hâkim görüşme formu: Yarı yapılandırılmış sorulardan oluşan form ilk olarak ağır ceza mahkemelerinde çalışan bir hâkim ile psikolojik danışmanlık ve rehberlik alanında doktora eğitimini tamamlamış bir aile mahkemesi uzmanı tarafından yüz ve kapsam geçerliği bakımından değerlendirilmiş ve geribildirimler doğrultusunda formun beş soruluk son hali elde edilmiştir. Form bu haliyle, ağır ceza mahkemesi geçmişi olan bir hâkimle denenmiş, formda herhangi bir sorun gözlenmemiştir.

Avukat görüşme formu: Beş sorudan oluşan bu form, ilk aşamada İzmir Barosu'na kayıtlı ve aile mahkemesinde yoğun çalışan bir avukata ve psikolojik danışmanlık alanında doktorasını tamamlayan bir aile mahkemesi uzmanına gönderilmiş ve bu uzmanlar tarafından yüz ve kapsam geçerliği boyutlarında değerlendirilmiştir. Geribildirimler ışığında revize edilen form, aile mahkemesinde sıklıkla dosyası bulunan bir avukat ile pilot uygulamaya tabi tutulmuş ve ikinci bir gözden geçirmeyle son haline kavuşmuştur.

Uzman görüşme formu: Araştırmacılar tarafından oluşturulan bu beş soruluk görüşme formunun ilk hali, psikolojik danışmanlık ve rehberlik alanında doktor öğretim üyesi olan bir akademisyene ve psikolojik danışmanlık alanında doktora eğitimini tamamlayan bir adli görüşmeciye gönderilerek yüz ve kapsam geçerliği bakımından sınanmıştır. Geribildirimler doğrultusunda ikinci kez düzenlenen formun adli görüşmeciyle gerçekleştirilen pilot uygulaması sonrasında forma son hali verilmiştir.

Mağdur görüşme formu: Yine araştırmacılar tarafından oluşturulan bu görüşme formunun ilk hali, psikolojik danışmanlık alanında doktor öğretim üyesi olan bir akademisyene ve adli tıp alanında doktora eğitimini tamamlamış bir adli görüşmeciye gönderilerek yüz ve kapsam geçerliği bakımından sınanmıştır. Geribildirimler doğrultusunda düzenlenen bu form, bir cinsel istismar mağduru ile pilot uygulama ile değerlendirilmiş ve forma son hali verilmiştir. Form toplamda beş sorudan oluşmaktadır.

\subsection{Sürec ve Verilerin Analizi}

T.C. Adalet Bakanlığı Mağdur Hakları Daire Başkanlığı ile Hâkimler ve Savcılar Kurulu'ndan gerekli izinlerin alınmasıyla birlikte katılımcılara telefon yoluyla ulaşılarak kendileriyle görüşme talep edilmiş ve katılım onayı alınan 10 hâkim, 10 avukat, 10 adli görüşmeci ve 10 mağdur ile $(n=40) 2019$ Şubat ayı içerisinde birinci araştırmacı tarafindan yüz yüze bireysel görüşmeler gerçekleştirilmiştir. Görüşme esnasında Hâkimler ve Savcılar Kurulu talepleri doğrultusunda ses ve görüntü kaydı alınamamış, veri kaybını olabildiğince önlemek amacıyla görüşmelerde yardımcı görüşmeci olarak İzmir 
Adliyesi’nde Pedagog olarak görev yapan bir uzman bulunmuştur. Her iki görüşmeci, katılımcıların yanıtlarını görüşme esnasında not almış ve görüşmeler sonrasında iki grup not karşılaştırılarak, verilerin geçerliği ve güvenirliği sağlanmaya çalışılmıştır. Tüm görüşmeler İzmir Adliyesi’nde katılımcıların kişisel çalışma odalarında gerçekleştirilmiştir.

Görüşmelerin tamamlanmasıyla birlikte veriler Betimsel Veri İndeksi formatına uygun olarak Word 2003 dosyasına aktarılmış ve iki araştırmacı tarafından bağımsız olarak analiz edilmiştir. Veriler, görüşmecilerin tuttukları görüşme notlarının birleştirilmesi sonucunda elde edilen metinden oluşmaktadır. Katılımcıların kimlik bilgilerinin gizli tutulması amacıyla Betimsel Veri İndeksi'ne aktarılan verilerde tüm katılımcılar için kodlar kullanılmıştır (örneğin H6, görüşülen altıncı hâkimi ifade etmiştir). Betimsel veri indeksi, katılımcılarla gerçekleştirilen görüşmelerde görüşmecilerin aldığı notların herhangi bir değişikliğe uğramadan aktarıldığı, notlardan elde edilen görüşlerin/olası kodların yazıldığı ve ek yorumların not edildiği üç sütundan oluşmaktadır.

Elde edilen veriler herhangi ses ya da görüntü formatında kayıt altına alınamadığından ve ikinci bir veri kaynağı kullanılamadığından, katılımcıların her soruya verdikleri yanıtlar bazında içerik analizi tekniğiyle analiz edilmiştir. Araştırmacılar bu aşamada, verileri detaylı okuyup Betimsel Veri İndeksi'nde yer alan ilgili sütunlara görüşlerini yazmışlardır. Görüşler daha sonra iki araştırmacı tarafından bağımsız olarak kategoriler haline getirilmiş ve iki grup bulgu, görüş birliği / görüş birliği + görüş ayrılığ $X 100$ formülü kullanılarak gözlemciler arası güvenirlik hesaplamasına tabi tutulmuştur. \%81,48 olarak hesaplanan bu katsayı ile bulguların güvenilir olduğu sonucuna varılmıştır (Huberman ve Miles, 1998). Görüş ayrılıkları iki araştırmacı tarafından gerçekleştirilen iki saatlik bir toplantıda ele alınmış ve görüş birliği oluşturulmuştur. Ayrıca her iki araştırmacı da, verilerin tema oluşturmak için uygun olmadığına kanaat getirmişler ve bulguları kategori ve frekanslar üzerinden raporlamayı uygun görmüşlerdir.

\section{Bulgular}

Dört grup katılımcıdan elde edilen bulgular, her grup ayrı başlıklar altında incelenmiştir. Bulgulara ilişkin verilen doğrudan alıntılar, herhangi bir değişiklik yapılmadan, görüşmeci notlarında olduğu şekliyle aktarılmıştır. Katılımcıların bazı sorulara birden fazla yanıt vermelerinden dolayı, görüş sayısı katılımcı sayısından yüksek çıkmıştır.

Hâkimlerden Elde Edilen Bulgular: Hâkimler beş soruya yönelik toplam 59 görüş bildirmişlerdir. Tablo 3 'te, yanıt kategorileri ve frekansları yer almaktadır. 
Tablo 3. Hâkimlerden elde edilen bulgular

\begin{tabular}{|l|c|c|}
\hline Kategori & Görüşler & $\mathrm{n}$ \\
\hline \multirow{3}{*}{ AGO'dan yararlanma } & 18 yaş altındakileri dinliyorum. & 5 \\
& 15 yaş altındakileri dinliyorum. & 3 \\
\hline AGO'nun çocuklar & AGO’yu tercih etmiyorum. & 2 \\
üzerindeki etkileri & AGO'da kendilerini rahat hissediyorlar. & 10 \\
\hline & AGO'da kendilerini güvende hissediyorlar. & 3 \\
AGO'yla ilgili genel & AGO çocukların üstün yararını gözeten doğru bir uygulama. & 10 \\
değerlendirme & AGO zaman alıcı bir uygulama. & 9 \\
& Teknik aksaklıklar süreci güçleştiriyor. & 6 \\
\hline AGO uygulamalarına ilişkin & AGO’nun doğrudanlığı etkilemesi değerlendirmeleri güçleştiriyor. & 3 \\
öneriler & Teknik aksaklıklar giderilmeli. & 6 \\
\hline Toplam görüş & Bekleme odasında yaşa uygun materyaller bulundurulmalı. & 2 \\
\hline
\end{tabular}

Soru 1. AGO uygulaması ile ilgili ne düşünüyorsunuz? Hâkimlerin tamamı AGOların cinsel istismar mağduru çocukların üstün yararı bakımından iyi ve doğru bir uygulama olduğunu belirtmiş, beş hâkim ise bu görüşlere ek olarak AGOların doğrudanlık ya da yüz yüzelik ilkesine ters düşmesi nedeniyle değerlendirmeleri güçleştirebilen bir uygulama olduğunu ifade etmişledir. Buna ilişkin olarak H5, "Mağdurun beyanının farklı bir yerdeyken alınması bence güzel bir uygulama. ... Fakat izlemek ve görmek arasında fark var. Mağdur bizi görmemeli, tamam ama bizim de onu görmemiz gerekiyor. Sonuçta ciddi bir suç var ve elimizdeki tek şey o çocuğun beyanı. Biz gene de heyet olarak çocuğu düşünerek, duruşma salonunda beyan almıyoruz. Sonuçta çocuğu düşünmek zorundayız." sözleriyle bir taraftan mağdurların üstün yararını savunurken diğer taraftan doğrudanlık gibi adalet sistemi için önemli gördüğü bir ilkeyi gündeme getirmiştir. H6 ise, mağdurun üstün yararını ön planda tuttuğunu şu sözlerle açıklamıştır: "Benim açımdan çok iyi bir uygulama oldu. ... Kendimi daha iyi hissediyorum. Sanığın mağduru görmesi ve aynı ortamda bulunmaları doğru bir uygulama değildi. Mağdurlar bu şekilde kendisini rahatlıkla ifade edebiliyor. Daha güvenli bir ortamda olduğunu ve zarar görmeyeceğini biliyor."

\section{Soru 2. AGO'dan hangi çocukların dinlenmesi sırasında yararlanıyorsunuz?} Hangi durumlarda yararlanmıyorsunuz? Hâkimlerin beşi 18 yaş altı, hâkimlerin üçü ise yalnızca 15 yaş altı mağdurların beyanlarında AGO'dan yararlandıklarını belirtirken, iki hâkim AGO’yu kullanmayı tercih etmediklerini ifade etmişlerdir. Örneğin H9, "Biz şimdiye kadar mağdurlarla ilgili bir sorun yaşamadı. Avukatlardan ya da taraflardan da bir talep gelmedi. Randevu alma, bağlanma ve mağdurla doğrudan iletişsim kurma ile ilgili sorunlar olduğu için adli görüşme odasını kullanmama kararı 
aldık. " sözleriyle, AGO’yu kullanmama gerekçeleri arasında teknik sorunları ve tarafların herhangi bir talebinin olmamasını göstermiştir.

Soru 3. Sizce AGO uygulamaları duruşmaların gidişatını nasıl etkiledi? Hâkimler genel olarak AGO’nun eski uygulamaya kıyasla zaman alıcı olduğunu belirtirken ( $\mathrm{n}=9$ ), altı hâkim buna gerekçe olarak ses-görüntü-bağlantı aksaklıklarını göstermişlerdir. Söz konusu güçlüklerin yanında, H3'ün çocuğun üstün yararını şu ilginç sözlerle dile getirmesi dikkate değerdir: "Evet, bunu inkâr edemem. Adli görüşme odası, mă̆duru dinleme zamanını uzattı ama biz burada mağdur için bulunmuyor muyuz? Onun orada bazen güldüğünü duyuyorum. Kaç yıldır hâkimim. Burada gülen mağdur görmedim. Çocuğun üstün yararı tam olarak bu.",

Soru 4. Sizce AGO’nun mağdurlara yönelik nasıl bir etkisi oldu? Hâkimlerin, tamamı çocukların AGO’da kendilerini daha rahat hissettiklerini beyan ederken, üç hâkim çocukların o ortamda kendilerini güvende hissettiklerini de eklemişlerdir. H7, "Ekran çok küçük. Jest ve mimik göremiyoruz. Gene de çocukların daha rahat oldukları fark ediliyor. Görüşen arkadaşlarımız daha iyi iletişime geçiyor. Burada gergin bir ortam var. Taraflar, kürsü, sanık, seyirciler, kâtipler, giren ve çıkanlar... Orada daha rahat olmaları kadar doğal bir şey yok” sözleriyle mağdur çocukların AGO uygulamasından yarar sağladıklarını açıklarken, aynı zamanda aile mahkemesi uzmanlarının da bu süreçteki etkili uygulamalarına dikkat çekmiştir.

Soru 5. AGO ile ilgili önerileriniz nelerdir? Hâkimlerin önerileri genel olarak AGO’nun teknik özellikleriyle ilgili öneriler vermişlerdir. Altı hâkim bağlantı için bekleme ve bağlantı sonrası ses-görüntü kalitesinin iyileştirilmesini talep ederken, ikisi odada her yaş grubuna uygun materyalin bulundurulması gerektiğini vurgulamıştır. Örneğin H8, AGO’daki materyal eksikliklerini “Biz hangi yaşta mağdur alsak, karşımızda aynı ortam oluyor. Her yaş grubu çocuk farklı. Bir de çocukların bireysel özellikleri farklı. Onlar için farklı şeyler gerekmez mi? Alan uzmanı değilim ama gerekir bence." ifadesiyle açıklarken aynı zamanda bireysel farklılıklara olan duyarlılı̆̆ını ortaya koymuştur. Tablo 3 'te, hâkimlerden elde edilen tüm bulgulara ilişkin frekans dağılımları sunulmuştur.

Aile Mahkemesi Uzmanlarından Elde Edilen Bulgular. A i le mahkemesi uzmanlarından elde edilen toplam 51 yanıtın açıklamaları ve frekansları Tablo 4 'te yer almaktadir. 
Tablo 4. Aile mahkemesi uzmanlarından elde edilen bulgular

\begin{tabular}{|l|c|c|}
\hline Kategori & Görüşler & $\mathrm{n}$ \\
\hline AGO'dan elde edilen kişisel yararlar & Daha planlı/programlı çalışabiliyorum. & 6 \\
& Mesleğimi daha nitelikli yürütebiliyorum. & 4 \\
\hline \multirow{2}{*}{ AGO'nun çocuklar üzerindeki etkileri } & Sanıkla karşılaşmamaya bağlı olarak çocuğu & 10 \\
& ikincil örselenmelerden koruyor. & \\
\hline AGO uygulamasının dezavantajları & Çocuk kendini daha rahat ifade edebiliyor. & 8 \\
\hline & İş yükünü artırıyor. & 7 \\
AGO uygulamalarına ilişkin öneriler & AGO sayıları artırılmalı. & 6 \\
& Çablosuz kulaklık temin edilmeli. & 4 \\
\hline Toplam görüş & Hâkinlere hizmet içi eğitim sağlanmalı. & 2 \\
\hline
\end{tabular}

Soru 1. AGO uygulaması ile ilgili ne düşünüyorsunuz? Uzmanların tamamı, çocuk mağdurları ikincil herhangi bir örselenmeden koruduğu gerekçesiyle etkili bir uygulama olduğunu savunmuşlardır. U2, bu görüşü şu sözlerle ifade etmiştir:

“Eski uygulama çok kötü bir uygulamaydı. Çocuk duruşma salonunda sanık ile aynı ortamda duruyordu. Ailesinin ve sanığın beyanını dinliyordu. Sonra ben talepte bulunuyordum ve heyet kabul ederse, duruşma salonu boşaltıllyordu. Bence bu çocuk için çok önemli bir de ğişiklik oldu. Ikincil mağduriyetlerin oluşmaması lazım”.

Uzmanların ikinci ve üçüncü sorulara verdikleri yanıtlar birbiriyle bağlantılı olduğundan, bu soruların bulguları bir arada verilmiştir.

\section{Soru 2. AGOların kurulmasıyla birlikte sizin görev ve sorumluluklarınızda neler} değişti? Soru 3. Bu değişiklikler sizi ne şekilde etkiledi? Memnun olduğunuz ve olmadığınız yönler nelerdir? Bu sorulara ilişkin farklı görüşler arasında AGO'nun iş yükünü artırması ( $\mathrm{n}=7$ ) şeklindeki olumsuz yanıtların yanında, mesleği daha nitelikli yürütebilme $(n=4)$ ve randevu sisteminin oturmasıyla birlikte daha planlı çalışabilme $(n=6)$ gibi olumlu yanıtlar da dikkat çekmiştir. U1 ve U10'la görüşmelerde elde edilen ve aşağıda yer alan görüşler, iş yükünün artmasına karşın mesleki doyumun daha ön planda görüldüğ̈ünü ispatlar niteliktedir:

“Eskiye göre sorumluluğumuz arttı. Eskiden sadece duruşma salonunda çocuğun yanında bulunuyorduk. Şu an ifadeyi almakla sorumluyuz. Bu bana kendimi daha iyi hissettiriyor. Mesleki açıdan daha fazla keyif alıyorum." (U1) 
"Bizim açımızdan oldukça olumlu oldu. Biz eskiden sadece beyanda bulunuyorduk çocukla ilgili. Şu an ise daha aktifiz. Çocukların odadan olumlu ayrılması, beni de sevindiriyor. Farklı disiplinlerin bakış açısını yansıtan bir şey bu. Bence oldukça iyi oldu herkes için." (U10)

Soru 4. Sizce AGO’nun mağdurlara yönelik nasıl bir etkisi oldu? Tüm katılımc1 uzmanlar, birinci soruya verdikleri yanitlara paralel olarak, bu soruda da olumlu görüş bildirmişlerdir. Dokuz uzman mağdurların sanıkla yüz yüze gelmek istemediklerini, AGO sayesinde duygusal olarak daha az oranda örselendiklerini, sekizi ise çocukların AGO'da kendilerini daha iyi ifade ettiklerini gözlediklerini açıklamışlardır. U9 AGO'nun mağdur çocuklar üzerindeki koruyucu etkilerini, "Çocuklar sanık ile karşılamak istemiyor. O yüzden adli görüşme odalart iyi bir uygulama. Burada onları koruyan bir yapı var." sözleriyle ifade etmiştir.

Soru 5. AGO ile ilgili önerileriniz nelerdir? Uzmanlar da, hâkimlerde olduğu gibi, AGO'da yaşanan teknik aksaklıkların giderilmesi yönünde öneriler getirmişlerdir. Altı uzman, adliyede yalnızca bir AGO olmasından ve bağlantının geç kurulmasından kaynaklı olarak mağdurların ifade vermek için uzun süre beklemek durumunda kaldıklarından AGO sayılarının artırılmasına yönelik çalışmalar yapılmasını önermişlerdir. Dört uzman ise duruşma salonu ile AGO arasındaki bağlantıyı kolaylaştıracak kablosuz kulaklık ve çocuklara yönelik materyal temini gibi fiziksel düzenlemelere dikkat çekmiş̧lerdir. Ayrıca iki uzman hâkimlere yönelik bir adli görüşme eğitiminin sağlanması gereğini beyan etmiştir. Hâkimlerin AGO uygulamasıyla ilgili bilgi düzeyini sorgulayan U3, buna yönelik şu sözleri sarf etmiştir: "Hâkimler henüz adli görüşme odasını tam kavrayamadılar. Randevuyu erken alyyorlar ama duruşmaya yeri geliyor, 5 saat sonra başlyyorlar. $O$ arada çocuk adli görüşme odasında mı beklemeli, yoksa ailesiyle duruşma salonu koridorunda mı? Bizim çocukları 5 saat bekletebilecek bir ortamımız yok. Bir mağduru 5 saat bekletmek de bence doğru değil."

Avukatlardan Elde Edilen Bulgular: Katılımcı avukatlardan toplam 68 görüş elde edilmiştir. Bu görüşler ve her kategoriye ilişkin frekans dağılımları Tablo 5'te görülmektedir. 
Tablo 5. Avukatlardan elde edilen bulgular

\begin{tabular}{|l|c|c|}
\hline Kategori & Görüşler & $\mathrm{n}$ \\
\hline \multirow{3}{*}{ AGO'dan yararlanma } & AGO talebinde bulunmuyorum. & 7 \\
& AGO talep ediyorum ancak reddediliyor. & 2 \\
& AGO talebinde bulundum ve kabul edildi. & 1 \\
\hline \multirow{2}{*}{ AGO'nun çocuklar üzerindeki etkileri } & Çocuklar kendini güvende hissediyor. & 7 \\
& Çocuklar kendilerini rahat ifade edebiliyorlar. & 6 \\
\hline \multirow{3}{*}{ AGO’yla ilgili genel değerlendirme } & Çocuğun üstün yararını gözeten başarılı bir uygulama & 10 \\
& AGO duruşma süreçlerini olumsuz anlamda etkilemedi. & 7 \\
& Teknik aksaklıklar var. & 3 \\
\hline \multirow{2}{*}{ AGO uygulamalarına ilişkin öneriler } & AGO 18 yaşın altındakilere uygulanmalı. & 6 \\
& Teknik aksaklıklar giderilmeli. & 5 \\
& Çocuklar için materyal sağlanmalı. & 5 \\
& AGOlar adliye dışıında olmalı. & 3 \\
\hline Toplam görüş & AGO 15 yaşın altındakilere uygulanmalı. & 2 \\
\hline
\end{tabular}

Soru 1. AGO uygulaması ile ilgili ne düşünüyorsunuz? Avukatların tamamı, hâkim ve uzmanların da görüşleriyle benzer şekilde, AGO uygulamasının mağdurun üstün yararına hizmet eden başarılı bir uygulama olduğunu ifade ederken, altı avukat 18 takvim yaşının, ikisi ise 15 takvim yaşının temel alınması gerektiğini, diğer ikisi de yaş fark1 gözetilmeksizin tüm cinsel istismar mağdurlarının AGO'da dinlenmesi gerektiğini beyan etmiştir. A8'in şu sözleri, 18 yaş üzeri mağdurların da AGO'da dinlenmeleri gereğini ortaya koymaktadır: "Adli görüşme odaları çok yerinde bir uygulama oldu. Mağdurun fazladan zarar görmesini engelledi. Yalnız benim girdiğim dosyada beş mağdur vardı. Dördü 18 yaşın altındaydı. Onlar adli görüşme odasında dinlendi. Diğer mă̆dur 18 yaşın ay farkıyla üzerindeydi. O duruşma salonunda dinlendi. Onun adına üzücü bir durum oldu. 18 yaş üstü mağdurlar da bence orada dinlenmeli”.

\section{Soru 2. Çocuk beyanlarının AGO'da alınmasına ilişkin talepte ya da itirazda bulunuyor} musunuz? Avukatların tamamı, üstlendikleri davalarda AGO kullanımına itirazda bulunmadıklarını, bunun yanında davalarda AGO talebinde de bulunmadıklarını $(\mathrm{n}=7)$ belirtmişlerdir. Ayrıca iki avukat AGO talebinde bulunduğunu, ancak bu talebin mahkeme heyetince reddedildiğini açıklamıştır. On katılımcı arasından yalnızca bir avukatın AGO talebinin yerine getirilmesi de ilginç bulgular arasında yer almıştır. A3, AGO talebinin reddedilmesine ilişkin deneyimini ve bundan AGO kullanımı lehine çıkarttığg sonucu şu şekilde dile getirmiştir: "Ben bir ilçe adliyesinde adli görüşme odasının kullanılmasını istedim. Adli görüşme odasına sistem üzerinden bağlanabileceklerini söyledim. Mahkeme uygun görmedi. Aynı durumu İzmir Adliyesi’nde de yaşadım. Yüz yüzelik ilkesi gereği 
duruşma salonunda dinlenmesi kararı alındı. Bence adli görüşme odası kullanımı zorunlu olmal. ". A6 ise, hizmet içi eğitimin uygulamada getirebileceği yararları şöyle açıklamıştır: "Ben bir baro eğitiminde adli görüşme odalarını öğrendim. Sonra bir duruşma sırasında talepte bulundum. Heyet kullandı. Bence çok da yararl bir uygulama oldu."

Soru 3. Sizce AGO uygulamaları duruşmaların gidişatını nasıı etkiledi? Avukatlar genel olarak AGO'nun duruşma sürecinde ciddi bir farklılığa yol açmadığı konusunda görüş bildirirken ( $\mathrm{n}=7$ ), üç avukat, hâkim ve uzman görüşleriyle paralel olarak sesgörüntü ve bağlanma gibi teknik aksaklıkların süreci uzattığından yakınmışlardır. Teknik aksaklıkların yarattığ 1 olumsuzluklara yönelik olarak A2 şu bildirimde bulunmuştur: "Genel gidişatı aslında etkiliyor. Bağlantı oluyor, olmuyor. Bekliyoruz. Sonra tam bir doğrudanlık olmadı̆ğ için, heyet anlamak için tekrar tekrar soruyor. Evet, çocuğun üstün yararı söz konusu ama böyle de bir boyutu var."

Soru 4. Sizce AGO’nun mağdurlara yönelik nasıl bir etkisi oldu? Avukatlar da, hâkim ve uzmanların görüşlerine benzer şekilde AGO'nun mağdurların kendilerini güvende hissetmelerine $(\mathrm{n}=7)$ ve kendilerini rahat ifade edebilmelerine $(\mathrm{n}=6)$ hizmet ettiğini öne sürmüşlerdir. A4'in şu ifadeleri, mağdurların üstün yararını gözettiğine dair bir kanıt oluşturmaktadır: "Adliye ortamı insanın kendisini güvende hissetmemesine neden oluyor. Ben en azından adli görüșme odasında güvende oldukların görebiliyorum. Bu beni mutlu ediyor. Onların rahat olmast önemli bence."

Soru 5. AGO ile ilgili önerileriniz nelerdir? Avukatların AGO uygulamasıyla ilgili önerileri, odaya sağlanması gereken materyaller ve teknik aksaklıkların giderilmesi yönünde diğer katılımcıların önerileriyle örtüşmektedir. Bununla birlikte üç avukatın, AGO'ların adliye dışında olması gerektiğine ilişkin önerileri ilginçtir. Katılımcılar buna gerekçe olarak, mağdur çocukların adliye gibi gerginlik verici ortamlardan uzak tutulmalarının iyi olabileceğini göstermişlerdir. Son olarak iki avukat, uzmanların ve hâkimlerin AGO eğitimi almaları gereğine değinmişlerdir. A7 buna ilişkin olarak "Uzmanlar için de hâkimler için de yeni bir uygulama. Ben iyi bir eğitim almalar gerektiğini düşünüyorum. Hâkimler teknik özelliklere pek hâkim değil. Uzmanlarla koordinasyon kuramıyorlar bazen. " yorumunu getirmiştir.

\section{Mağdur Çocuklardan EIde Edilen Bulgular}

Çocuk katılımcılar, ifade verecekleri ortam olarak mahkeme salonu ile AGO'yu karşılaştırdıkları toplam 50 görüş bildirmişler ve bu görüşlerin AGO lehine olduğu belirlenmiştir. Görüss kategorileri ve frekansları Tablo 6'da sunulmuştur. 
Tablo 6. Mağdur çocuklardan elde edilen bulgular

\begin{tabular}{|l|c|c|}
\hline Kategori & Görüşler & $\mathrm{n}$ \\
\hline $\begin{array}{l}\text { Mahkeme salonunda ifade } \\
\text { vermeye yönelik görüşler }\end{array}$ & Mahkeme salonunda ifade vermek istemiyorum. & 10 \\
& $\begin{array}{c}\text { Adliyeye ifade vermek için gelirken çok gerildim. } \\
\text { İfademin AGO'da alınacağını öğrendim ve orayı merak ettim. }\end{array}$ & 7 \\
\hline \multirow{2}{*}{ AGO uygulamasıla ilgili } & İfademin AGO'da alınmasını isterim. & 10 \\
olumlu görüşler & AGO'da kendimi rahat hissettim. & 8 \\
& Ortamda farklı kişiler olmadığı için rahat ifade verdim. & 5 \\
\hline Toplam görüş & Kendimi güvende hissettim. & 4 \\
\hline
\end{tabular}

Soru 1. Adliyeye gelirken kendini nasıl hissetmiştin? Mağdurların bu soruya verdikleri yanıtların tümünün olumsuz duygulanımı içerdiğini söylemek mümkündür. Yedi katılımcı, beyanının AGO yerine duruşma salonunda alınacağını düşündüğü için kendisini kötü hissettiğini beyan ederken, iki katılımcı beyanının AGO' da alınacağını bildiğini ve o ortamı merak ederek geldiğini beyan etmiştir. M3, bu süreçteki gerginliğini ve sonrasında AGO'da olmaktan duyduğu memnuniyeti şu sözlerle dile getirmiştir: "Ben adliyeye gelirken, duruşma salonuna gideceğimi, o kişinin (sanığın) da orada olacağını sanıyordum. 2 aydır düşünüyordum. Buraya gelmek daha iyi oldu. Mutluyum.'”

Soru 2. AGO’da bulunmak nasıl bir duyguydu? Mağdurların bu soruya ilişkin yanıtlarının olumlu olduğu gözlenmiştir. Sekiz katılımcı AGO’da kendini rahatlamış, dördü ise güvende hissettiğini belirtmiştir.

Soru 3. Beyanın duruşma salonunda alınacak olsaydı, ne hissederdin? Tüm katılımcılar duruşma salonuna gitmeyi tercih etmediklerini beyan etmişlerdir. Bir katılımcı, duruşma salonunda karşılaşacağı kalabalıktan ve özellikle de sanıkla aynı ortamda olmaktan duyacağı üzüntüyü şöyle ifade etmiştir: "Ben oraya asla gitmek istemezdim. Ailem, insanlar, hâkimler ve o adam (sanık)... Orada olsaydım muhtemelen üzülürdüm.” (M4).

Soru 4. AGO'da hoşuna giden ve seni rahatsız eden şeyler nelerdi? Katılımcıların bu soruya yönelik olumlu görüşleri, diğerlerinin olmadığı bir ortamda ifade vermenin getirdiği rahatlık $(n=5)$ ve adli görüşmecinin olumlu yaklaşımları $(n=4)$ etrafında toplanmıştır. Beş katılımcı ise ifade vermek için beklemek durumunda kalmalarından yakınmışlardır.M7, AGO'nun olumlu ve olumsuz getirilerini şu şekilde özetlemiştir: "Burada beklemek... Sabah geldim ve şu an akşam. Daha az bekleyebilirdim. Görüşme iyiydi ama. Abla (Adli görüşmeci) benimle hep ilgilendi. Hep nasıl olduğumu sordu." 
Soru 5. Sence AGO genel olarak nasıl bir uygulama? Tüm katılımcı çocuklar, AGO’nun kendileri için doğru bir uygulama olduğuna dair görüş bildirmişlerdir.

\section{Tartıșma}

Türkiye'deki cinsel istismar mağdurları için uygulamaya konan AGO uygulamasına yönelik yürüttüğümüz ve bir anlamda bu konuda öncü kabul edilebilecek bu araştırma, durumu farklı açılardan değerlendirebilmek amacıyla AGO süreciyle birebir bağlantılı olan hâkim, avukat, aile mahkemesi uzmanı ve mağdur gibi çoklu veri kaynaklarına başvurarak gerçekleştirilmiştir. Araştırmada dikkat çeken ilk sonuç, tüm katılımcılar tarafindan AGO'nun mağdurlar açısından ikincil mağduriyetlerin önlenmesini sağlayan ve mağdurun beyanda bulunmasını kolaylaştıran bir uygulama olarak değerlendirilmesidir. Söz konusu ortak görüşler, genel yaşam içerisinde çocuk ve insan hakları, adli sistem içerisinde ise Adalet Bakanlığı'nın 2015-2019 Stratejik Planı'nda yer alan Çocuklara yönelik adli süreçlerde özel önlemlerin etkin hâle getirilmesi ilkesi (Ermağan-Çağlar ve Türk, 2019; Mağdur Hakları Daire Başkanlığı, 2017) bağlamlarında yüz güldürücü gelişmelerin varlığını düşündürmektedir.

\subsection{Hâkimlerin Penceresinden AGO Değerlendirmeleri}

AGO uygulamasına ilişkin katılımcı görüşlerinin olumlu olmasının yanında, uygulamaların düşünce ya da tutumlarla her daim paralel ilerlemesi söz konusu olmayabilmektedir ve nitekim bulgular, uygulamaların katılımcıların tutumlarından farklı seyredebildiğini göstermiştir. Bu konuyla ilgili tartışmaya, çocuğun üstün yararı kavramını temel alarak girmek uygun gibi görünmektedir. Bulgularda da açık olarak görülebileceği gibi, hemen tüm katılımcılar AGO’nun çocuk için olumlu ve olması gereken bir uygulama olduğuna dair görüş birliği sergilemişlerdir. Bununla birlikte, özellikle hâkimlerin doğrudanlık ilkesini oldukça önemsedikleri, AGO'nun bu ilkeyi belirli oranda ihlal ettiğini belirtmeleri ve bununla doğru orantılı olarak bazılarının duruşmalarda AGO uygulamasından yararlanmayabildikleri görülmektedir. Bu durumda, AGO uygulamasının doğrudanlık ilkesini ne derece etkilediğini değerlendirmek gerekir. Doğrudanlık ya da diğer adiyla yüz yüzelik, yazılı beyan yerine kişisel ifadenin daha anlaşılır sonuçlar doğuracağını, ilgili kişilerin yargılamayla ilgili doğrudan bilgilendirilebileceğini, ifade veren bireyin görüş ve taleplerini açıkça ifade edebileceğini ve mahkemenin daha hızlı ve pratik bir şekilde bilgiye ulaşacağını öne süren bir ilkedir (Arslan, 2012). AGO uygulaması bu doğrultuda incelenecek olursa, pedagojik altyapısı olan aile mahkemesi uzmanları mağdurlara hakları ve dosya kapsamı hakkında bilgi vermekte, mağdurların olası sorularını uygun şekilde 
yanıtlamakta ve onların duygu ve düşüncelerini mümkün olduğunca az örselenerek ifade etmelerini sağlamaktadırlar. Bu görüşme sürecinde duruşma hâkimleri de teknoloji yardımıyla odaya dâhil olup uzman aracılığıyla sorularını doğrudan iletebilmekte, mağdurun olası sorularını yanıtlayabilmekte ve kapalı devre televizyon sistemi yoluyla doğrudan gözlem yapabilmektedirler. Dolayısıyla AGO uygulamasında hâkimler ve avukatlar, mağdura tüm sorularını iletebilirler ve duruşma salonuyla aradaki tek fark, soruyu ileten kişinin bir aile mahkemesi uzmanı olmasıdır (Şamar, 2018). Bu açıdan bakıldığında, AGO'nun doğrudanlık ilkesini ciddi boyutta ihlal etmediğini söylemek mümkündür.

Uzun yıllardır devam eden cinsel istismar mağdurlarının hâkimler tarafından duruşma salonunda dinlenmesi uygulamasından AGO uygulamasına geçişin bazı hâkimler tarafından kaygı verici olması belirli ölçüde anlaşılır bir durum olarak kabul edilebilir. Öncelikle mesleki alışkanlıklar söz konusudur ve hâkimlerin henüz yaygınlaşma aşamasında olan AGO uygulamalarına uyum sağlamaları gerekecektir. Uyum sağlama sürelerini olabildiğince kısaltmamın yolu ise, hâkimlere bu alanda hizmet içi eğitim sağlamaktan geçmektedir. Hâkimlerin kaygılarını haklı çıkarabilecek ikinci bir husus ise, adil sistemdeki dosya yoğunluğunun ve kamu davalarının ivedilikle çözülmesine ilişkin taleplerin hâkimler üzerinde baskı yaratıyor olmasıdır. Dolayısıyla AGO'nun önemli yararlarının yanında uygulamaya istendik şekilde geçirilememesinin tek başına hâkim tutumlarıyla açıklanması, tabloyu eksik görmemize neden olacaktır ve bu nedenle diğer katılımcılardan elde edilen sonuçları da incelemek gerekmektedir.

\subsection{Avukatların Penceresinden AGO Değerlendirmeleri}

Katılımcı avukatlar, cinsel istismar davalarında çocuğun üstün yararını gözettiklerini ancak uygulamalarında AGO'dan sık yararlanmadıklarını, dolayısıyla da (hâkimlerle benzer şekilde), tutumları ve davranışları arasında çelişkiler olduğunu ortaya koymuşlardır. Bu noktada, bazı avukatların AGO taleplerinin geri çevrildiğine dair açıklamaları akılda tutulmalıdır ve bu durum, avukatların üstün yarar ilkesini gözetiyor olsalar dahi, bir anlamda uygulamadan mahrum bırakıldıklarını göstermektedir. Bulgulara dönülecek olursa, 10 katılımcıdan yalnızca üçünün AGO talebinde bulunduğu görülmektedir ki bunun düşük bir oran olduğu söylenebilir. Avukatlar arasında AGO taleplerinin artırılması gereği ortadadır ve bunu sağlamanın en etkili yollarından birinin hizmet içi eğitim olduğu düşünülmektedir. Bulgular bölümünde de yer aldığı gibi, A6, hizmet içi eğitim sonrasında bir davada AGO talep ettiğini ve sürecin verimli olduğunu açıklamıştı. Tek bir örnek olmakla birlikte, bu katılımoının deneyiminin, hizmet içi eğitimin etkililiğine dair önemli bir beyan olduğu düşünülebilir. 
Kuşkusuz ki, yalnızca bir ilde niteliksel bir araştırma yöntemi çerçevesinde gerçekleştirilen bu çalışmadan yola çıkarak, avukatların AGO taleplerine yönelik bir genelleme yapmak doğru olmayacaktır ancak bu bulgu, Türkiye'deki diğer illerde de durumun benzer olup olmadığı konusunda soru işaretleri uyandırmaktadır. Diğer illerde yapılacak araştırmalarda benzer bir durumla karşılaşılacak olunursa, avukatların ülke genelinde AGO uygulamalarına ilişkin bilinçlendirilmeleri çalışmaları kaçınılmaz görünmektedir. Dolayısıyla hâkimlerle birlikte avukatların da hizmet içi eğitim olanaklarından yararlandırılmaları gereği ortaya çıkmaktadır.

Araştırma sorularıyla doğrudan ilgili olmamakla birlikte, avukatların görüşmelerde gündeme getirdikleri ilginç bir konu, AGO kullanımı ve mağdur yaşı ilişkisi olmuştur. Avukatların, AGO'nun hangi yaş grubu için uygun olduğuna dair görüşleri 15 yaş altı, 18 yaş altı ve tüm yaşlar için uygulanması gibi farklı görüşleri içermiştir. 18 yaş alt1, kuram ve uygulamada çocukluk çağ 1 olarak kabul edilen yaş dönemini (Papalia ve Wendkos-Olds, 1992; Vasta, Haith ve Miller, 1992) ve Çocuk Koruma Kanunu'nda yer alan yaş aralığını ifade etmesi, yaş sınırlaması olmaması görüşü ise genel bağlamda insan haklarını gözetmesi bakımından anlaş1lır görüşlerdir. Burada dikkat çeken nokta, 15 yaşın iki katılımcı tarafından AGO'dan yararlanma sınırı olarak belirtilmesidir ki bu yaş gelişimsel bir dönüm noktasına denk gelmemekte ve yasal bir boyuta dayandırılamamaktadır. Araştırmacılar bu konuda gerçekleştirdikleri alanyazın taramasında herhangi bir sonuca ulaşamamışlar ve konuyu alandaki bir uzmana danışmaya karar vermişlerdir. Bu doğrultuda 05.04.2019 tarihinde ikinci araştırmacı tarafından bir Yargıtay hâkimiyle telefon yoluyla iletişime geçilmiştir. Yargıtay hâkimi, araştırmacıların görüşleriyle benzer şekilde, 18 yaş sınırının Çocuk Koruma Kanunu ölçütleri dâhilinde anlamlı bir görüşü içerebildiğini, 15 yaş sınırının ise büyük olasılıkla şikâyetçi olma durumunun hâkimler tarafından bireylere sorulabildiği yaş olmasından dolayı avukatlar tarafından sınır olarak kabul edildiğini açıklamıştır (Telefonla iletişim, 5.4.2019). Yargıtay hâkiminin söz konusu görüşünün gerçeği yansıttı̆̆ııı varsayacak olursak, 15 yaşın, ergenlerin örseleyici olaylardan olumsuz etkilenmemeye başladıkları yaş olduğuna dair dünya genelinde herhangi bir bilimsel araştırma olmadığına dikkat çekmek isteriz. Dolayısıyla avukatların, gelişim dönemlerindeki bireylerin, bir diğer deyişle çocuk ve ergenlerin örseleyici olaylar karşısındaki duygusal etkilenimlerini dikkate almaları ve bu doğrultuda tutum değişikliğine gitmeleri konusunda bilinçlendirilmeleri gereği ortaya çıkmaktadır. 


\subsection{Aile Mahkemesi Uzmanlarının Penceresinden AGO Değerlendirmeleri}

Aile mahkemesi uzmanları açısından bakıldığında, uzmanlar iş yüklerinin artmasının yanında, AGO uygulamasının iş doyumlarını belirli ölçüde artırdığını da vurgulamışlardır. İş doyumu ve çalışan verimliliği arasındaki doğrudan ilişki dikkate alındığında, AGO'nun uzmanlar tarafından etkili bir şekilde yürütülmekte olduğu ya da en azından yürütülmeye çalışıldığı varsayılabilir. Ne var ki, etkili uygulamalar sistematiklik gerektirmekte, bir diğer deyişle bir uzmanın aynı uygulamaları diğer uzmanlarla benzer şekilde belirli bir sistematik süreç bünyesinde yürütmesi gerekmektedir. Türkiye'de AGO görüşmelerini yürüten uzmanlar için öneri kılavuzları olmasına karşın, uzmanların belirli bir görüş̧me protokolü eğitimi almadıkları bilinmektedir. Oysa adli görüşmelerin ortak bir protokol çerçevesinde yürütülmesi, mağdurlardan alınan ifadelerin güvenilirliğini artıracak ve çocuğun üstün yararı ilkesini gözetecek şekilde uzmanlar için bir yol haritası oluşturacaktır. Buna ilişkin olarak Ermağan-Çağlar ve Türk (2019), Bulgaristan, Endonezya, İsveç ve daha pek çok ülkede kullanılan NICHD Protololü'nü önerdikleri çalışmalarında, protokolün uzmanların her aşamada çocuk mağdurları örselemeden doğru bilgileri alabilecekleri sistematik bir görüşme formatını tanıtmışlardır. Toth'un (2011) da belirttiği gibi, bu ya da benzeri protokollerin adli sistemlere dâhil edilmesi çok yönlü yararlara işaret etmektedir ve Türk Adli Sistemi'nde de benzer uygulamaların aile mahkemesi uzmanlarının mesleki yeterliklerine eklenmesiyle, AGO uygulamalarının daha etkili işlemesi söz konusu olacaktır.

\subsection{Cinsel İstismar Mağduru Çocukların Penceresinden AGO Değerlendirmeleri}

Cinsel istismar mağduru katılımcı çocuklardan elde edilen bulgular, AGO'nun kendileri için oldukça yararlı bir uygulama olduğu yönünde sonuçlara işaret etmiştir. Bu sonuca, katılımcıların tümü beyanlarının bir uzman tarafından alınmasının yoğun kaygılarını azalttığını ve AGO ortamında kendilerini rahat hissettiklerini belirtmelerinden ulaşmak mümkündür. Kaygının azalması ise, çocuk için ikincil bir örselenmesinin önüne geçmektedir. Kaygının çocuklar ve ergenler üzerindeki ciddi etkilerini, 2016'daki bir gazete haberinde görmek mümkündür. Habere göre, araştırmanın yürütüldüğü İzmir'de bir cinsel istismar mağduru çocuk, sanık ile yüzleşeceği duruşma günü öncesi heyecandan kalp krizi geçirerek yaşamını yitirmiştir (Yıldırım, 2016). Bu ve benzeri sonuçların olabildiğince engellenmesi adına, AGO uygulamasının yaygınlaşması ve cinsel istismar davalarında zorunlu hale getirilmesi doğru olacaktır. Çocuğun üstün yararı ilkesini gözetmekle birlikte, uzmanın da cinsel istismar olayıyla ilgili daha sağlıklı bilgilere ulaşılmasını kolaylaştıran bir uygulama olmasından dolayı (Cronch ve diğerleri, 2006; 
Cross ve diğerleri, 2007; Ermağan-Çağlar ve Türk, 2019), AGO’nun adaletin sağlanmasını kolaylaştırabileceği de bu noktada vurgulanmalıdır.

\subsection{AGO Uygulamaları ve Yasal Mevzuat}

AGOların yakın geçmişte açılmasına, bunun yanında yeterli ölçüde hizmet içi eğitimlerin gerçekleştirilmemiş olmasına karşın, görüşme yapılan sekiz mahkemenin adli görüşme odası uygulamasını kullanması yüz güldürücü, iki mahkemenin cinsel istismar mağdurlarını duruşma salonunda dinlemeyi sürdürmesi ise aynı ölçüde düşündürücüdür. Burada ilgili yasal düzenlemelerden söz etmek gerekecektir. Çocukların duruşma salonunda dinlenmesi uygulamasında, mağdurun nasıl dinleneceği ile ilgili herhangi bir yönetmelik ya da yasal düzenleme bulunmamaktadır. Cinsel istismar mağduru duruşma salonunda dinlenirken, "Sanık ortamda olacak mı?”, "Cinsel istismar mağdurunun ailesi duruşma salonunda olacak mı?”, "Duruşmayı takip eden seyirciler olacak mı?”, "Duruşmada bulunan uzmanın görev ve sorumlulukları nelerdir? " gibi soruların belirli bir yanıtı bulunmamakta, uygulamanın nasıl olacağı tamamıyla mahkeme heyetinin tercihine bırakılmaktadır. $\mathrm{Ne}$ var ki, cinsel istismar mağduruyla ilgili gerekli tedbirlerin tam olarak yerine getirilmediği ve/veya sürecin hâkimlerin inisiyatiflerine bırakıldığı bir ortamda çocuğun üstün yararından da söz edilemeyeceği açıktır. Yine bu konuyla ilişkili olarak, bazı katılımcı hâkimlerin, AGO uygulamasına yönelik avukatlardan ya da ailelerden herhangi bir talebin gelmediğini ifade etmeleri de, yasal sürecin belirsizliğinin yanında, ilgili kişilerin de AGO ile ilgili bilgi yetersizliklerini ortaya koymaktadır. Müşteri taleplerinin yaşamın her alandaki uygulamaları değiştirme gücü günümüzde su götürmez bir gerçektir ve benzer taleplerin aileler ve avukatlar tarafından da adli süreçlerde gündeme getirilmesine yönelik bilinçlendirme çalışmalarının başlatılması gereği ortadadır.

\subsection{AGO Uygulamalarında Karşılaşılan Güçlükler ve Çözüm Önerileri}

Tüm katılımcı gruplarda AGO’nun yararlarına ilişkin dile getirilenlerin yanında, hâkimler, avukatlar ve aile mahkemesi uzmanlarının belirttikleri teknik sorunlar da, bu araştırmanın önemli bulguları arasındadır. Teknik aksaklıklar, bazı durumlarda bir uygulamanın tercih edilmemesinde başlı başına bir gerekçe olabilmektedir. Bu araştırmada her ne kadar AGO'nun yeterince kullanılmaması hâkim ve avukatların mesleki alışkanlıkları ve hizmet içi eğitimlerin yetersizliğine dayandırılmış olsa da, teknik sorunların da AGO uygulamasının önüne geçen kritik bir gerekçe olabileceği düşünülmektedir. Nitekim duruşma salonu ile AGO arasındaki iletişimin aksaması duruşma süresini uzatacak ve hâkimin mağdurun yanıtlarına sağlıklı şekilde ulaşmasını engelleyecek ya da odadaki materyal yetersizliği 
uzmanın sağlıklı değerlendirme yapmasını ve mağdura ulaşmasını güçleştirecektir. Böyle bir durumda da, AGO’nun etkili bir uygulama olacağını iddia etmek güçtür. Dolayısıyla katılımcıların belirttikleri teknik sorunların çözüme kavuşturulması için gerekli alt yapının bir an önce oluşturulması kritik olup, söz konusu düzenlemelerin aynı zamanda yasal boyutta da bir zorunluluk teşkil ettiği (Ermağan-Çağlar ve Türk, 2019; Mağdur Hakları Daire Başkanlığı, 2017) akıldan çıkarılmamalıdır.

\section{Son Notlar}

$\mathrm{Bu}$ araştırma, hâkimler, avukatlar, aile mahkemesi uzmanları ve cinsel istismar mağduru çocukların, çocuğa yönelik cinsel istismar davalarında AGO uygulamasının gerekli ve yerinde bir yaklaşım olduğunu düşündüklerini ortaya koymuştur. Türkiye'de henüz emekleme aşamasında olan bu uygulamanın bazı açılardan geliştirilmesi gerektiği de, yine katılımcı görüşlerinden elde edilen önemli bir sonuçtur. Öncelikle, hâkimlerin, avukatların ve aile mahkemesi uzmanlarının süreçteki sorumluluklarını etkili şekilde yerine getirebilmeleri için kendilerine hizmet içi eğitimlerin sağlanması gereği dikkat çekmiştir. Teknik yetersizlikler ise, sürecin etkili işleyebilmesi adına bir an önce ele alınması gereken etmen olarak ortaya çıkmıştır. Hizmet içi eğitimler, görevlerin teknik boyutlarını yerine getirmek için bilgilendirmenin yanında, üç meslek grubunun da iletişimini ve işbirliğini artırıcı bir sorumluluğu da almalıdır, nitekim katılımcılardan elde edilen bazı bulgular, tarafların birbirlerinin görev ve sorumluluklarına dair yeterli bilgi sahibi olmadıkları yönündedir.

AGO uygulamalarının iyileştirilmesiyle birlikte, ülke genelinde yaygınlaştırma çalışmalarının yürütülmesi de bir o kadar önemli görünmektedir. Yaygınlaşma, farklı illerdeki çocuk mağdurların eşit düzeyde uygun muameleyi görmelerini sağlayacak ve toplumda da bu uygulamaya ilişkin farkındalığı artırarak yaygınlaşmasını daha da hızlandıracaktır. Bu aynı zamanda, uygulamanın hâkim inisiyatifinden çıkarılarak ülke genelinde zorunlu hale getirilmesine de önayak olabilecektir. Elbette bu yaygınlaştırma sürecinde, AGO’nun etkililiğine dair bilimsel araştırmaların yürütülmesi de uygulamanın giderek iyileştirilmesinde kilit bir etmen olacaktır.

\footnotetext{
Hakem Değerlendirmesi: Dış bağımsız.

Çıkar Çatışması: Yazarlar çıkar çatışması bildirmemiştir.

Finansal Destek: Yazarlar bu çalışma için finansal destek almadığını beyan etmiştir.

Peer-review: Externally peer-reviewed.

Conflict of Interest: The authors have no conflict of interest to declare.

Grant Support: The authors declared that this study has received no financial support.
} 


\section{Kaynakça/References}

Acehan, S., Bilen, A., Ay, M.O., Gülen, M., Avci, A., ve İçme, F. (2013). Çocuk istismarı ve ihmalinin değerlendirilmesi. Arşiv Kaynak Tarama Dergisi, 22(4), 591-614.

Anderson, J., Ellefson, J., Lashley, J., \& Miller, A.L. (2009). The CornerHouse forensic interview protocol: RATAC. Thomas M. Cooley Journal of Practical \& Clinical Law, 12, 193-330.

Arslan, A.S. (2012). Doğrudanlık ilkesi. Süleyman Demirel Üniversitesi Hukuk Fakültesi Dergisi, 4(2), 133-144.

Aydemir, İ., ve Yurtkulu, F. (2012). Çocuğa yönelik cinsel istismarla mücadelede çocuk izlem merkezi. Ankara Sağllk Bilimleri Dergisi, 1(2), 151-165.

Azzopardi, C., Alaggia, R., \& Fallon, B. (2018). From Freud to feminism: Gendered constructions of blame across theories of child sexual abuse. Journal of Child Sexual Abuse, 27(3), 254-275.

Bağ, Ö., ve Alşen, S. (2016). Çocuğun cinsel istismarının değerlendirilmesinde yeni model: Çocuk İzlem Merkezleri. İzmir Dr. Behçet Uz Çocuk Hastanesi Dergisi, 6(1), 9-14.

Bilginer, S.Ç., ve Çalışkan, D. (2018). Çocuğu istismardan korumada yeni bir yaklaşım: Çocuk izlem merkezleri. Y. Karaman-Kepenekci ve P. Taşkın (Eds.), Prof. Dr. Emine Akyüz'e armağan: Akademisyenlikte 50 yıl. Çocuk haklarl, eğitim hukuku, vatandaşlık eğitimi içinde (ss. 119-127). Ankara: Pegem Akademi.

Blakemore, T., Herbert, J.L., Arney, F., \& Parkinson, S. (2017). The impacts of institutional child sexual abuse: A rapid review of the evidence. Child Abuse \& Neglect, 74, 35-48.

Bracewell, T.E. (2018). Outcry consistency and prosecutorial decisions in child sexual abuse cases. Journal of Child Sexual Abuse, 27(4), 424-438.

Cronch, L.E., Viljoen, J.L., \& Hansen, D.J. (2006). Forensic interviewing in child sexual abuse cases: Current techniques and future directions. Aggression and Violent Behavior, 11(3), 195-207.

Cross, T.P., Jones, L.M., Walsh, W.A., Simone, M., \& Kolko, D. (2007). Child forensic interviewing in Children's Advocacy Centers: Empirical data on a practice model. Child Abuse \& Neglect, 31(10), 1031-1052.

Demirel, B., ve Atalar, U. (2017). Çocuğun cinsel istismarı ve olaya ilişkin mağdurun ifade alınması süreci. Journal of Current Researches on Social Sciences, 7(3), 221-232.

Ermağan-Çağlar, E., ve Türk, T. (2019). İstismara maruz kalan çocuklarla adli görüşme: NICHD Protokolü önerisi. Türkiye Adalet Akademisi Dergisi, 11(38), 393-412.

Ernberg, E., Magnusson, M., \& Landström, S. (2018). Prosecution of child sexual abuse cases involving preschoolaged children: A study of Swedish cases from 2010 to 2014. Journal of Child Sexual Abuse, 27(7), 832-851.

Glesne, C., \& Peshkin, A. (1992). Becoming qualitative researchers. New York: White Plains.

Hornor, G., \& Zeno, R. (2018). Child sexual abuse perpetrators: What forensic nurses need to know. Journal of Forensic Nursing, 14(4), 206-213.

Huberman, A.M., \& Miles, M.B. (1998). Data management and analysis methods. N.K. Denzin \& Y.S. Lincoln (Eds.), Collecting and interpreting qualitative materials (pp. 179-210). London: Sage Publications.

Joki-Erkkilä, M., Niemi, J., \& Ellonen, N. (2018). Child sexual abuse: Initial suspicion and legal outcome. Forensic Science International, 291, 39-43.

Koçtürk, N., ve Yılmaz, D. (2018). Çocuk istismarı ve ihmali için risk altındaki çocukları belirlemeye ve müdahale etmeye yönelik model/veri tabanı önerisi. Kastamonu Ĕ̈itim Fakültesi Dergisi, 26(6), 1919-1927.

Krause-Parello, C.A., Thames, M., Ray, C.M., \& Kolassa, J. (2018). Examining the effects of a service-trained facility dog on stress in children undergoing forensic interview for allegations of child sexual abuse. Journal of Child Sexual Abuse, 27(3), 305-320.

Lamb, M.E., Orbach, Y., Hershkowitz, I., Esplin, P.W., \& Horowitz, D. (2007). A structured forensic interview protocol improves the quality and informativeness of investigative interviews with children: A review of research using the NICHD Investigative Interview Protocol. Child Abuse \& Neglect, 31(11-12), 1201-1231.

Mağdur Hakları Daire Başkanlığı (2017). Adli görüşme odasl yönetmeliği. http://www.cigm.adalet.gov.tr/images/ ago-yonetmelik.pdf adresinden edinilmiştir. 
Mağdur Hakları Daire Başkanlığı (2019). Adli görüşme odası bulunan adliyeler. http://magdur.adalet.gov.tr/ adli-gorusme-odasi-bulunan-adliyeler-01554 adresinden edinilmiştir.

Masilo, D.T. (2018). Prevention of child sexual abuse within the family system: Guidelines for an educational social group work program. Journal of Child Sexual Abuse, 27(1), 1-12.

Merriam, S. B. (2013). Nitel araştırma: Desen ve uygulama için bir rehber. Nobel Yayıncılık.

Papalia, D.E., \& Wendkos-Olds, S. (1992). Human development (5th ed.). New York: McGraw \& Hill.

Pérez-Fuentes, G., Olfson, M., Villegas, L., Morcillo, C., Wang, S., \& Blanco, C. (2013). Prevalence and correlates of child sexual abuse: A national study. Comprehensive Psychiatry, 54(1), 16-27.

Pilgrim, D. (2017). Child sexual abuse: From diagnosis to formulation. Educational \& Child Psychology, 34(4), 40-49.

Popović, S. (2018). Child sexual abuse news: A systematic review of content analysis studies. Journal of Child Sexual Abuse, 27(7), 752-777.

Rellini, A.H. (2014). Sexual abuse and sexual function. In G. Corona, E.A. Jannini \& M. Maggi (Eds.), Emotional, physical and sexual abuse: Impact in children and social minorities. (pp. 61-71). New York: Springer.

Renvoize, J. (2017). Innocence destroyed: A study of child sexual abuse. New York: Routledge.

Sağlık Bakanlığı (2019). ÇİM listesi. https://khgmsaglikhizmetleridb.saglik.gov.tr/TR,43119/cocuk-izlemmerkezi-cim-listesi.html adresinden edinilmiştir.

Scoglio, A.A., Kraus, S.W., Saczynski, J., Jooma, S., \& Molnar, B.E. (2019). Systematic review of risk and protective factors for revictimization after child sexual abuse. Trauma, Violence, \& Abuse, 20(1), 1-13.

Somekh, B. (2006). Action research: A methodology for change and development. Berkshire: Open University Press.

Şamar, B. (2018). Mağduriyet bağlamında adli sosyal hizmet ve adli görüşme odalart: Eskişehir Adliyesi örneği. Yayımlanmamış yüksek lisans tezi, Kocaeli Üniversitesi Sosyal Bilimler Enstitüsü, Kocaeli.

T.C. Adalet Bakanlığı Ceza İşleri Müdürlüğü Mağdur Hakları Daire Başkanlığı, (2017). Adli görüşme odaları: AGO uygulaması için temel hukuk bilgisi. http://www.magdur.adalet.gov.tr/images/ago-hukuk.pdf adresinden edinilmiştir.

Taner, H.A., Çetin, F.H., Işı, Y. ve İşeri, E. (2015). Cinsel istismara uğrayan çocuk ve ergenlerde psikopatoloji ve ilişkili risk etkenleri. Anatolian Journal of Psychiatry, 16, 294-300.

Tetteh, P.M., \& Markwei, U. (2018). Situating the notion of "gbekefons" in the discourse of child sexual abuse among the Ga in Accra, Ghana. Journal of Child Sexual Abuse, 27(5), 510-522.

Toth, P. (2011). Comparing the NICHD and RATAC child forensic interview approaches: Do the differences matter?. APSAC Advisor, 23, 15-20.

Tweedlie, J., \& Vincent, S. (2019). Adult student nurses' experiences of encountering perceived child abuse or neglect during their community placement: Implications for nurse education. Nurse Education Today, 73, 60-64.

Vasta, R., Haith, M.M., \& Miller, S.A. (1992). Child psychology: The modern science. New York: John Wiley \& Sons.

Yıldırım, A., ve Şimşek, H. (2013). Sosyal bilimlerde nitel araştırma yöntemleri. İstanbul: Seçkin Yayıncılık.

Yıldırım, T. (2016, 25 Kasım). Taciz mağduru küçük kızın kalbi duruşma stresine dayanamadı. Hürriyet. http:// www.hurriyet.com.tr/gundem/taciz-magduru-kucuk-kizin-kalbi-durusma-stresine-dayanamadi-40287871 adresinden edinilmiştir. 